\title{
Mechanical evaluation of quad-helix appliance made of low-nickel stainless steel wire
}

\author{
Rogério Lacerda dos Santos논 Matheus Melo Pithon²
}

Objective: The objective of this study was to test the hypothesis that there is no difference between stainless steel and low-nickel stainless steel wires as regards mechanical behavior. Force, resilience, and elastic modulus produced by Quadhelix appliances made of 0.032-inch and 0.036-inch wires were evaluated. Methods: Sixty Quad-helix appliances were made, thirty for each type of alloy, being fifteen for each wire thickness, 0.032-in and 0.036-in. All the archwires were submitted to mechanical compression test using an EMIC DL-10000 machine simulating activations of 4, 6, 9, and 12 $\mathrm{mm}$. Analysis of variance (ANOVA) with multiple comparisons and Tukey's test were used $(\mathrm{p}<0.05)$ to assess force, resilience, and elastic modulus. Results: Statistically significant difference in the forces generated, resilience and elastic modulus were found between the 0.032-in 0.036-in thicknesses ( $p<0.05$ ). Conclusions: Appliances made of lownickel stainless steel alloy had force, resilience, and elastic modulus similar to those made of stainless steel alloy.

Keywords: Orthodontic appliances. Hypersensitivity. Nickel.

Objetivo: o objetivo do presente estudo foi testar a hipótese de não haver diferença no desempenho mecânico entre fios de aço inoxidável e fios de aço inoxidável com baixo teor de níquel. Avaliar, também, a força, a resiliência e o módulo de elasticidade produzidos pelos aparelhos quadri-hélice confeccionados com fio de 0,032" e 0,036". Métodos: foram confeccionados 60 aparelhos quadri-hélice. Desses, 30 para cada tipo de liga, sendo 15 confeccionados com fio de 0,032" e 15 com fio 0,036". Todos os arcos foram submetidos a teste de compressão mecânica em máquina EMIC DL-10000, simulando 4, 6, 9, e 12mm de ativação. A análise de variância e comparação múltipla (ANOVA) e o teste de Tukey foram utilizados $(\mathrm{p}<0,05)$ para avaliação da força, resiliência e módulo de elasticidade. Resultados: observou-se diferença estatisticamente significativa entre forças produzidas, resiliência e módulo de elasticidade entre as espessuras 0,032" e 0,036" ( $\mathrm{p}<0,05)$. Conclusão: os aparelhos confeccionados com liga de aço inoxidável com baixo teor de níquel apresentaram liberação de força, resiliência e módulo de elasticidade semelhantes aos aparelhos que utilizaram a liga de aço inoxidável.

Palavras-chave: Aparelhos ortodônticos. Hipersensibilidade. Níquel.

${ }^{1}$ Specialist in Orthodontics, Federal University of Alfenas - UNIFAL. MSc and $\mathrm{PhD}$ in Orthodontics, Federal University of Rio de Janeiro - UFRJ. Associate Professor of Orthodontics, Federal University of Campina Grande - UFCG. ${ }^{2}$ Specialist in Orthodontics, UNIFAL. MSc and PhD in Orthodontics, UFRJ. Assistant Professor of Orthodontics, Southwest Bahia University - UESB.
How to cite this article: Santos RL, Pithon MM. Mechanical evaluation of quad-helix appliance made of low-nickel stainless steel wire. Dental Press J Orthod. 2013 May-June;18(3):35-8.

Submitted: February 18, 2009 - Revised and accepted: August 14, 2009

» The authors report no commercial, proprietary or financial interest in the products or companies described in this article.

Contact address: Rogério Lacerda dos Santos

Universidade Federal de Campina Grande/Centro de Saúde e Tecnologia Rural Av. dos Universitários, S/N - Rodovia Patos / Teixeira - Brazil CEP: 58.700-970 - Patos/PB - E-mail: lacerdaorto@hotmail.com 


\section{INTRODUCTION}

In orthodontic practice, a variety of metal alloys, such as stainless steel, cobalt-chrome, nickeltitanium and beta-titanium are used, the majority of which contain nickel. ${ }^{11}$ The percentage of nickel in brackets and auxiliary appliances used in orthodontics ranges from $8 \%$ (in stainless steel wires) to over $50 \%$ (in nickel-titanium wires). ${ }^{7,17}$

Among the austenitic steels most commonly used in Orthodontics, types 302 and 304 are outstanding, according to the American Institute of Steel and Iron, AISI), containing approximately 18\% chrome and $8 \%$ nickel, which is represented by the $18-8$ group of stainless steels.

Nickel is a strong immunologic sensitizer, and may result in hypersensitivity ${ }^{14}$ and tissue reactions. These reactions may consist of intraoral diffuse red zones, blisters and ulcerations that may extend to the perioral area. In addition, there may be urticariform and eczematous reactions in the face or in more distant areas of the body. ${ }^{12}$

Therefore, to solve this problem, stainless steel alloys with low nickel content began to be used for fabricating appliances, among them the expanders used for the correction of posterior tooth crossbite. These can be used in primary, mixed and permanent dentition as an alternative for patients who present high allergenic potential.

The appliances commonly used for correcting dental crossbite include the Coffen, "W" arch and Quad-helix arch appliances. ${ }^{1,3,20}$

Graber ${ }^{9}$ affirmed that $400 \mathrm{~g}$ would be the lowest orthopedic force required to achieve an effect in the maxillary arch. Inversely, the correction of posterior tooth cross bite requires orthodontic forces, and Jarabak and Fizzell ${ }^{15}$ recommended ideal levels of force for each group of teeth. They suggested that to move a maxillary molar, a force of $250 \mathrm{~g}$ should be used.

Thus, the aim of this study was to test the hypothesis that there would be no difference in the mechanical performance between stainless steel wires and stainless steel wires with a low nickel content when evaluating force, resilience and modulus of elasticity produced by the Quad-helix appliance used for correcting posterior tooth crossbite, and to determine the ideal activation levels for each appliance.

\section{MATERIAL AND METHODS}

Sixty Quad-helix appliances were tested, using two wire thicknesses (0.032-in and 0.036-in), two types of metal alloys, the first being stainless steel (stainless steel-CrNi, Morelli, Sorocaba, São Paulo, Brazil) and the second low-nickel stainless steel nickel content below $0.2 \%$ (Biowire-CrMo, Morelli, Sorocaba, São Paulo, Brazil). Of these, 30 were made of each type of alloy, with 15 being made of 0.032-in and 15 of 0.036-in.

The Quad-helix appliances made had 2 external and internal segments, $40 \mathrm{~mm}$ and $35 \mathrm{~mm}$ long, respectively, 1 anterior section $10 \mathrm{~mm}$ in extension and 4 helical spirals with $1.5 \mathrm{~mm}$ in diameter (Fig 1).

The samples were fabricated by the same professional, using patterns of a single model with the same intercanine and intermolar distances. A segment measuring $5 \mathrm{~mm}$ long and 0.040 inches in diameter of a telescopic tube was attached to the posterior part of each external extremity of the Quad-helix appliance, to enable the application of force on the maxillary permanent first molars. A $10 \mathrm{~mm}$ long stainless steel wire 0.032 -in in diameter was silver-welded to the center of the telescopic tube, so that the appliance could be fixed to a universal test machine. ${ }^{16}$

Each sample was initially activated to $12 \mathrm{~mm}$, and after this it was submitted to a series of compression tests in an EMIC DL 10000 machine, using the Mtest program version 1.0 , at a speed of $5 \mathrm{~mm} / \mathrm{min}$. The Mtest program generated the mean force, resilience

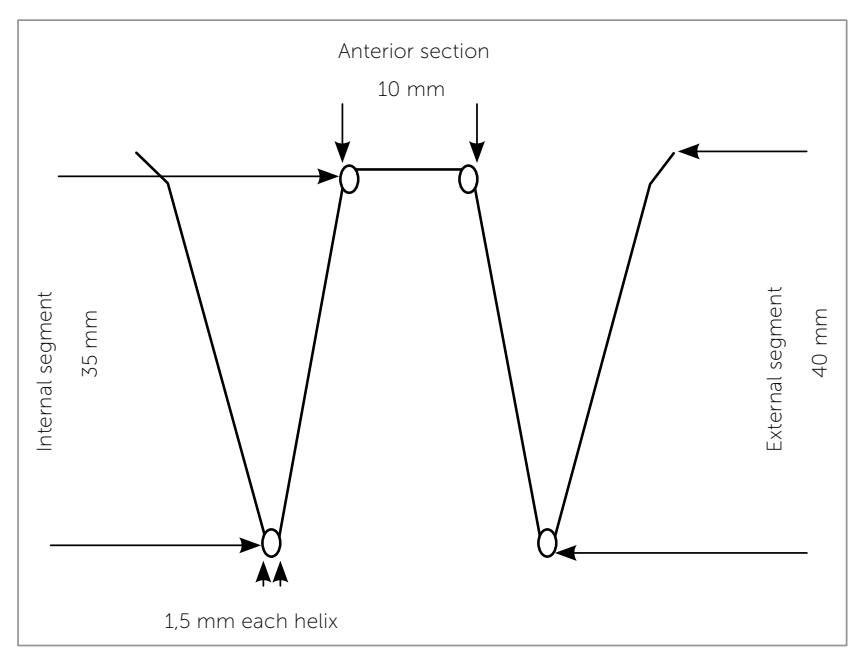

Figure 1 - Diagram used for fabricating the Quad-helix appliance. 
Table 1 - Mean force (g) produced by the Quad-helix appliances.

\begin{tabular}{|c|c|c|c|c|c|}
\hline \multicolumn{2}{|c|}{ Quad-helix appliance } & \multicolumn{4}{|c|}{ Activation } \\
\hline Metal alloy & Wire diameter & $4 \mathrm{~mm}$ & $6 \mathrm{~mm}$ & $9 \mathrm{~mm}$ & $12 \mathrm{~mm}$ \\
\hline Stainless steel & 0.032 -in & $108.8 \pm 11^{a}$ & $136.9 \pm 16^{a}$ & $189.6 \pm 15^{\mathrm{a}}$ & $221.2 \pm 12^{a}$ \\
\hline Stainless steel & $0.036-$ in & $123.9 \pm 8^{b}$ & $172.1 \pm 11^{b}$ & $245.8 \pm 18^{b}$ & $291.5 \pm 24^{b}$ \\
\hline Low-nickel stainless steel & 0.032 -in & $110.8 \pm 0^{a}$ & $139.9 \pm 7^{a}$ & $193.1 \pm 10^{a}$ & $224.2 \pm 12^{a}$ \\
\hline Low-nickel stainless steel & 0.036 -in & $126.4 \pm 14^{b}$ & $175 \pm 15^{b}$ & $250.3 \pm 20^{b}$ & $316.1 \pm 22^{b}$ \\
\hline
\end{tabular}

$\mathrm{N}=15$, for each combination between metal alloy and wire diameter used. Different letters indicate statistically significant difference ( $p<0.05$ ) between appliances for the same activation.

Table 2 - Resilience and modulus of elasticity produced by the Quad-helix appliances

\begin{tabular}{|c|c|c|c|}
\hline \multicolumn{4}{|c|}{ Quad-helix appliance } \\
\hline Metal alloy & Wire diameter & Resilience (g/cm) & Modulus of elasticity $\left(\mathrm{g} / \mathrm{cm}^{2}\right)$ \\
\hline \multirow{2}{*}{ Stainless steel } & 0.032 -in & $146.4 \pm 13^{a}$ & $84.7 \pm 7^{a}$ \\
\hline & 0.036 -in & $195 \pm 15^{b}$ & $86 \pm 6^{b}$ \\
\hline \multirow{2}{*}{ Low-nickel stainless steel } & 0.032 -in & $149.8 \pm 9^{a}$ & $86.7 \pm 11^{\mathrm{a}}$ \\
\hline & 0.036 -in & $197.4 \pm 17^{b}$ & $87 \pm 12^{b}$ \\
\hline
\end{tabular}

$N=15$, for each combination between metal alloy and wire diameter used. Different letters indicate statistically significant difference ( $p<0.05$ ).

and modulus of elasticity produced by the activations of 4, 6, 9 and $12 \mathrm{~mm}$, as well as a graph of the mechanical behavior at these activation indices. The results obtained were statistically compared by one-way ANOVA and Tukey's tests.

\section{RESULTS}

The low-nickel stainless steel showed greater release of force, resilience and modulus of elasticity compared with conventional stainless steel (Tables 1 and 2).

In both alloys evaluated, the groups using 0.036 inch wire showed statistically higher $(p<0.05)$ levels of force, resilience and modulus of elasticity when compared with appliances made with 0.032-in wire.

For the same wire thickness there was no statistically significant difference between the alloys $(\mathrm{p}>0.05)$ (Tables 1 and 2).

\section{DISCUSSION}

The mean force values increased proportionally to the activations, which is in agreement with the fact that the appliances operated in the elastic phase, in which deformation is proportional to force. Resilience is the property associated with the capacity of absorbing and releasing energy; therefore, the greater the resistance, the more continuous the force will be. ${ }^{19}$
Studies have reported various forms of palatal arches in the correction of posterior crossbite. ${ }^{1,5,23}$ In the present study, the Coffen appliances showed distinct mechanical properties, indicating the need for knowledge about their performance in order to choose them. In addition, it is important to identify the etiology of the malocclusion and determine the ideal force for each treatment ${ }^{10}$ to be performed. The movement of a single molar may require $250 \mathrm{~g},{ }^{15}$ but orthopedic effects are perceptible in primary and mixed dentition with forces greater than $400 \mathrm{~g} .{ }^{9}$

Urbaniak et $\mathrm{al}^{23}$ in their study observed that the force produced by activation of the Quad-helix appliance is influenced by the size and diameter of the appliance wire. In this study it was verified that the quantity of wire used in fabricating the palatal arch and the force used are inversely proportional, and that the wire diameter is directly proportional to the force.

In other studies on the Quad-helix ${ }^{3,5,6}$ the use of a force of approximately $400 \mathrm{~g}$ was suggested for an activation of $8 \mathrm{~mm}$.

In view of the results obtained in this study, adequate treatment of cross bite of a single molar, or group of a few teeth is obtained with the Quad-helix appliance made with 0.036 inch wire, with $9 \mathrm{~mm}$ of activation, irrespective of the metal alloy. 
The findings showed that the force produced by activations of up to $12 \mathrm{~mm}$ with Quad-helix appliances made with 0.036 inch stainless steel alloy or low-nickel stainless steel wire were below $400 \mathrm{~g}$. This force is insufficient for achieving orthopedic effects, whether associated with the use of a fixed appliance, or not. Therefore its use would be invalid for this type of treatment.

Nickel is known for its allergenic potential. ${ }^{13,18,22}$ It is estimated that $4.5 \%$ to $28.5 \%$ of the population is hypersensitive to nickel, ${ }^{4,14,18,21}$ with greater prevalence for the female gender. For every 10 women, 1 man presents allergy to nickel. ${ }^{18}$ The presence of metal ions such as nickel in orthodontic appliances has been associated with hypersensitivity reactions. ${ }^{2}$

The clinical manifestations of hypersensitivity to nickel are easy to diagnose. When faced with an allergic condition, any intraoral or extraoral appliance that contains nickel must be removed until the signs of adverse effects in the mucosa or skin have completely healed. ${ }^{7}$ Previous history of allergy must be considered a predictive factor of clinical manifestations of hypersensitivity to nickel. ${ }^{8}$ Therefore, instead of using intra and extraoral appliances that contain nickel, it is suggested that they should be replaced by nickel-free, or low-nickel stainless steel brackets and wires.

Low-nickel stainless steel wire is an option the orthodontist may use in patients with a history of hypersensitivity to nickel, however, the patient should be aware of the activation that will be used in appliances made of this wire. The function of nickel is to stabilize the metal alloy. A reduction in its quantity will alter the physicochemical properties of the alloy. This alteration may generate an increase in rigidity of the orthodontic wire.

The Quad-helix appliance fabricated with lownickel stainless steel presented greater release of force when compared with the conventional steel alloy, and this may have a significant influence of the proposed treatment, by obtaining greater tooth movement than expected.

\section{CONCLUSION}

1) The low-nickel stainless steel showed release of force, resilience and modulus of elasticity similar to conventional stainless steel.

2) Quad-helix appliances produced adequate forces for orthodontic treatment, when their clinical application is correctly planned.
1. Adams CP. The design and construction of removable orthodontic appliances. Bristol: John Wright and Sons; 1969

2. Bass JK, Fine H, Cisneros GJ. Nickel hypersensitivity in the orthodontic patient. Am J Orthod Dentofacial Orthop. 1993:103(3):280-5.

3. Bell RA, Lecompte EJ. The effects of maxillary expansion using a quadhelix appliance during the deciduous and mixed dentitions. Am J Orthod. 1981;79(2):152-61.

4. Blanco-Dalmau L, Carrasquillo-Alberty H, Silva-Parra J. A study of nickel allergy. J Prosthet Dent. 1984:52(1):116-9.

5. Chaconas SJ, Caputo AA. Observation of orthopedic force distribution produced by maxillary orthodontic appliances. Am J Orthod. 1982;82(6):492-501.

6. Chaconas SJ, De Alba Y, Levy JA. Orthopedic and orthodontic applications of the quad-helix appliance. Am J Orthod. 1977:72(4):422-8.

7. Eliades T, Athanasiou AE. In vivo aging of orthodontic alloys: implications for corrosion potential, nickel release, and biocompatibility. Angle Orthod. 2002;72(3):222-37.

8. Genelhu MC, Marigo M, Alves-Oliveira LF, Malaquias LC, Gomez RS. Characterization of nickel-induced allergic contact stomatitis associated with fixed orthodontic appliances. Am J Orthod Dentofacial Orthop. 2005:128(3):378-81.

9. Graber TM, editor. Current orthodontics. Concept and technique. Philadelphia: WB Saunders; 1969.

10. Graber TM. Orthodontics. Current principles and practice. St. Louis: Mosby; 1985.

11. Grimsdottir MR, Gjerdet NR, Hensten-Pettersen A. Composition and in vitro corrosion of orthodontic appliances. Am J Orthod Dentofacial Orthop. 1992;101(6):525-32
12. Hensten-Pettersen A, Jacobsen N, Grimssdóttir MR. Allergic reactions and safety concerns. In: Brantley WA, Eliades T, editors. Orthodontic materials: scientific and clinical aspects. Stuttgart: Thieme; 2001. p. 287-99.

13. Jacobsen N, Hensten-Pettersen A. Occupational health problems and adverse patient reactions in orthodontics. Eur J Orthod. 1989;11(3):254-64.

14. Janson GR, Dainesi EA, Consolaro A, Woodside DG, Freitas MR. Nickel hypersensitivity reaction before, during, and after orthodontic therapy. Am J Orthod Dentofacial Orthop. 1998;113(6):655-60.

15. Jarabak JR, Fizzell JA. Aparatología del arco de canto com alambres delgados. Buenos Aires: Mundi; 1975.

16. Martinelli FL, Couto OS, Ruellas AC. Three palatal arches used to correct posterior dental crossbites. Angle Orthod. 2006;76(6):1047-51

17. Park HY, Shearer TR. In vitro release of nickel and chromium from simulated orthodontic appliances. Am J Orthod. 1983:84(2):156-9

18. Peltonen L. Nickel sensitivity in the general population. Contact Dermatitis. 1979:5(1):27-32

19. Phillips RW. Skinners science of dental materials. Philadelphia: WB Saunders; 1973. p. 23-7.

20. Proffit WR. Contemporary orthodontics. St. Louis: Mosby; 1986.

21. Schäfer T, Böhler E, Ruhdorfer S, Weigl L, Wessner D, Filipiak B, et al. Epidemiology of contact allergy in adults. Allergy. 2001;56(12):1192-6.

22. Schubert H, Berova N, Czernielewski A, Hegyi E, Jirásek L, Kohánka V, et al. Epidemiology of nickel allergy. Contact Dermatitis. 1987:16(3):122-8

23. Urbaniak JA, Brantley WA, Pruhs RJ, Zussman RL, Post AC. Effects of appliance size, arch wire diameter, and alloy composition on the in vitro force delivery of the quad-helix appliance. Am J Orthod Dentofacial Orthop. 1988;94(4):311-6. 